\title{
Adenosine Acting at an A1 Receptor Decreases N-Type Calcium Current in Mouse Motoneurons
}

\author{
Michelle Mynlieff and Kurt G. Beam \\ Department of Physiology, Colorado State University, Fort Collins, Colorado 80523
}

The neuromodulator adenosine is known to decrease neurotransmitter release at the neuromuscular junction by activation of an $\mathrm{A} 1$ adenosine receptor coupled to a pertussis toxin-sensitive G protein. Among the mechanisms that could contribute to the depression of neurotransmitter release is reduced entry of calcium through channels located in the presynaptic terminal. In the present study, we have examined the effects of adenosine on high-voltage-activated (HVA) calcium currents in motoneurons, the presynaptic cells of the neuromuscular junction. The motoneurons were isolated from embryonic mice, placed in primary tissue culture for 16 $\mathrm{hr}$, and analyzed by means of the whole-cell patch-clamp technique. Adenosine $(40 \mu \mathrm{M})$ reduced both transient and sustained components of HVA calcium current. This effect was blocked by the $A 1$ antagonist 8-cyclopentyltheophylline (CPT; $100 \mathrm{~nm}$ ) and was mimicked by the $A 1$ agonist $\mathrm{N}^{6}$ cyclohexyladenosine (CHA; $50 \mathrm{~nm}$ to $10 \mu \mathrm{M}$ ) but not by the A2a agonist 2-p-(2-carboxyethyl)phenethylamino-5' $-N$ ethylcarboxamido adenosine (CGS-21680; $1 \mu \mathrm{m}$ ). Pretreatment with pertussis toxin $(200 \mathrm{ng} / \mathrm{ml},>16 \mathrm{hr})$ abolished the depression of HVA calcium current by adenosine receptor activation. Brief ( $3 \mathrm{~min}$ ) exposure of the cells to $10 \mu \mathrm{M} \omega$-conotoxin GVIA irreversibly blocked a part of the HVA current, which can therefore be attributed to N-type channels; the remaining current was unaffected by adenosine receptor activation. Hence, it appears that adenosine decreases only the N-current portion of HVA current and that this inhibition occurs via an A1 receptor linked to a pertussis toxin-sensitive $\mathrm{G}$ protein. Other investigators have shown that $\mathrm{N}$-type channels do not play a primary role in eliciting transmitter release at the mammalian neuromuscular junction. Thus, it is uncertain what motoneuronal functions are influenced by adenosine modulation of $\mathrm{N}$-type channels.

[Key words: adenosine, purinergic receptor, $A 1$ receptor, N-current, $\mathrm{N}$-channels, mouse motoneurons]

Adenosine has been shown to decrease neurotransmitter release at both peripheral (Ginsborg and Hirst, 1972; Fredholm, 1976; Verhaege et al., 1977) and central synapses (Dolphin and Archer, 1983; Prince and Stevens, 1992). At the best-characterized peripheral synapse, the neuromuscular junction, exogenous and

Received July 23, 1993; revised Nov. 10, 1993; accepted Nov. 24, 1993.

This research was supported by National Institute of Neurological Disorders and Stroke Grant NS-26416 to K.G.B. M.M. was supported by an individual National Institutes of Health postdoctoral fellowship (NS-08769).

Correspondence should be addressed to Michelle Mynlieff, Ph.D., Department of Biology, Marquette University, 530 North 15 th Street, Milwaukee, WI 53233. Copyright (C) 1994 Society for Neuroscience $0270-6474 / 94 / 143628-07 \$ 05.00 / 0$ endogenous adenosine have been shown to decrease both electrically evoked (Ginsborg and Hirst, 1972; Ribeiro and Walker, 1975; Ribeiro and Sebastiao, 1987) and potassium-evoked (Miyamoto and Breckenridge, 1974; Silinsky, 1988) release of the neurotransmitter ACh. ATP, which is copackaged with $\mathrm{ACh}$ in the synaptic vesicles of motoneurons, is broken down to adenosine upon release into the synaptic cleft (Smith and Lu, 1991) and this adenosine acts on presynaptic receptors to decrease further transmitter release. This effect at the neuromuscular junction has been shown to be mediated in rodents by an A1 adenosine receptor (Sebastiao et al., 1990) and is abolished by pretreatment with pertussis toxin, indicating the involvement of a $\mathrm{G}$ protein.

In principle, multiple mechanisms could be involved in the depressive effect of adenosine on $\mathrm{ACh}$ release at the neuromuscular junction. In the hippocampus, adenosine has been shown to activate a resting potassium conductance, thereby hyperpolarizing the cell membrane and decreasing cell excitability (Gerber et al., 1989). Adenosine has been shown to reduce highvoltage-activated (HVA) calcium currents in dorsal root ganglion cells (Dolphin et al., 1986; Gross et al., 1989) and in CA1 (Scholz and Miller, 1991) and CA3 (Mogul et al., 1993) hippocampal pyramidal cells, suggesting that another possible mechanism by which adenosine might decrease neurotransmitter release would be to act directly on the voltage-gated calcium channels controlling this release. Mechanisms that do not involve effects on ionic currents (e.g., a decrease in the releasable pool of neurotransmitter or an inhibition of release processes that operate subsequent to calcium entry) have also been suggested for both the rat hippocampus (Scholz and Miller, 1992) and the frog neuromuscular junction (Hunt et al., 1992; Silinsky and Solsona, 1992).

To explore the role of reduced calcium current, the studies presented here used whole-cell voltage clamping to cxamine the effects of adenosine on voltage-dependent calcium currents in identified mouse motoneurons. Motoneurons were selected for investigation because they are the presynaptic cell type in one of the most accessible and best-characterized synapses, the neuromuscular junction. We have found that adenosine decreases $\mathrm{N}$-type current in mouse motoneurons. Like the depression of neuromuscular transmission by adenosine, the inhibition of $\mathrm{N}$-type current occurs via an A1 adenosine receptor linked to a pertussis toxin-sensitive $G$ protein. However, $N$-type channels do not appear to be important for neuromuscular transmission in the mouse since transmission is not blocked by $\omega$-conotoxin (Olivera et al., 1984; Sano et al., 1987). Thus, the decrease in $\mathrm{N}$-type current that is caused by adenosine seems unlikely to play a role in the inhibition of transmitter release at the mouse neuromuscular junction. 


\section{Materials and Methods}

Mouse motoneuron culture. The labeling, dissociation, and culturing of identified mouse motoneurons were carried out as previously described (Mynlieff and Beam, 1992a). Briefly, 14 d mouse embryos were decapitated and eviscerated, followed by injection of a suspension of the carbocyanine dye dil $\left(1,1^{\prime}\right.$-dioctoadecyl-3,3,3',3'-tetramethylindocarbocyanine perchlorate; Molecular Probes, Eugene, OR) into all four limbs of each fetus. The diI was suspended at $2.5 \mathrm{mg} / \mathrm{ml}$ in $20 \%$ ethanol/ $80 \%$ rodent Ringer solution with $0.1 \%$ bovine serum albumin. The rodent Ringer solution contained (in $\mathrm{mm}$ ) $146 \mathrm{NaCl}, 5 \mathrm{KCl}, 2 \mathrm{CaCl}_{2}, 1$ $\mathrm{MgCl}_{2}, 10 \mathrm{~N}$-2-hydroxycthylpiperazinc- $N^{\prime}$-2-cthanesulfonic acid (HEPES), and 11 glucose, pH 7.4. After being injected with dil, the fetuses were rinsed in oxygenated rodent Ringer, laminectomized, and then incubated at $35^{\circ} \mathrm{C}$ for 5-6 $\mathrm{hr}$ in oxygenated "perfusion medium" (minimum essential medium with Earle's salts supplied by GIBCO, Grand Island, $N Y$, with the addition of $2 \mathrm{~mm}$ glutamine, $10 \mathrm{~mm} \mathrm{NaHCO}_{3}$, $1 \mathrm{~mm}$ pyruvate, $10 \mathrm{~mm}$ HEPES, $100 \mu \mathrm{g} / \mathrm{ml}$ streptomycin, $60 \mu \mathrm{g} / \mathrm{ml}$ penicillin, $5 \mu \mathrm{g} / \mathrm{ml}$ insulin, and $50 \mu \mathrm{g} / \mathrm{ml}$ transferrin, $\mathrm{pH} 7.6$ ). The spinal cords were dissected free and all of the meninges and dorsal root ganglia were carefully removed. The isolated spinal cords were rinsed in PIPES (piperazine- $N, N^{\prime}$-bis(2-ethanesulfonic acid)-buffered saline (in mM: 120 $\mathrm{NaCl}, 5 \mathrm{KCl}, 1 \mathrm{CaCl}_{2}, 1 \mathrm{MgCl}_{2}, 20$ PIPES, and 25 glucose, $\mathrm{pH} 7.0$ ), cut into small pieces $\left(<1 \mathrm{~mm}^{3}\right)$, and incubated in oxygenated PIPES-buffered saline containing $0.1 \%$ type XI trypsin and $0.01 \%$ DNase I (both from Sigma, St. Louis, MO) for $30 \mathrm{~min}$ at $35^{\circ} \mathrm{C}$. The tissue was rinsed once with $1-2 \mathrm{ml}$ of warm "mouse spinal medium" $(80 \%$ perfusion medium without transferrin or insulin, $15 \%$ fetal bovine serum, and $5 \%$ chick embryo extract), triturated with a fire-polished pipette in mouse spinal medium, and plated onto culture dishes that had been coated with poly-L-lysine (4-15 kDa; $1 \mathrm{mg} / \mathrm{ml}$ in $0.15 \mathrm{~m}$ boric acid, $\mathrm{pH} 8.4$ ). To provide muscle growth factors, the majority of dishes had previously been plated around their edges $\left(5 \times 10^{4}\right.$ cells $/ 35 \mathrm{~mm}$ dish $)$ with dissociated neonatal mouse myoblasts (described previously in Adams and Beam, 1989) less than 1 week prior to the addition of the spinal neurons. Occasionally the spinal neurons were plated on poly-L-lysine-coated dishes without myotubes around the edge. No differences were seen in the currents under these conditions but fewer motoneurons survived the culturing procedure. Cells were maintained in a humidified atmospherc of $95 \%$ air $/ 5 \% \mathrm{CO}_{2}$ at $37^{\circ} \mathrm{C}$. Dissociated motoneurons were identified by the presence of dil labeling (viewed with optics appropriate for rhodamine).

Electrophysiology. The initial experiments characterizing the effects of adenosine were all performed on identified motoneurons 12-24 hr after the dissociation procedure. Because many more motoneuron-like cells survived the culture procedure when the $5 \mathrm{hr}$ dil labeling procedure was eliminated, subsequent experiments characterizing the identity of the adenosine receptor mediating the response were performed on unlabeled spinal neurons that had diameters greater than $15 \mu \mathrm{m}$ and exhibited a motoneuron-like morphology. No differences were seen in comparing the currents from labeled motoneurons and unlabeled motoneuron-like cells. For all of the results it is specified whether identified motoneurons or unlabeled motoneuron-like cells were used.

Currents were measured with the whole-cell configuration of the patchclamp technique (Hamill et al., 1981) with a Dagan 3900 patch clamp (Minneapolis, MN). The patch electrodes (3-5 M 2 ) were pulled from soda-lime glass, coated with wax to reduce capacitance, and filled with internal solution (in $\mathrm{mm}$ ): $140 \mathrm{Cs}$-aspartate, $5 \mathrm{MgCl}_{2}, 10 \mathrm{Cs}_{2}$ ethylene glycol-bis( $\beta$-aminoethyl ether)- $N, N, N^{\prime}, N^{\prime}$-tetra-acetic acid (EGTA), 10 HEPES, $1 \mathrm{Na}_{2}$ ATP, $0.1 \mathrm{Na}_{2}$ GTP, pH 7.4. The external solution for measuring calcium channel currents contained (in $\mathrm{mM}$ ) $10 \mathrm{MeCl}_{2}, 145$ tetraethylammonium-Cl, 0.001 tetrodotoxin, and 10 HEPES, pH 7.4 with $\mathrm{CsOH}$, in which the charge carrier $\left(\mathrm{Me}^{2+}\right)$ was either $\mathrm{Ca}^{2+}$ or $\mathrm{Ba}^{2+}$.

Currents elicited by $300 \mathrm{msec}$ test steps, applied from a holding potential of $-80 \mathrm{mV}$, were electronically filtered at $1 \mathrm{kHz}$ and digitally sampled every $1.5 \mathrm{msec}$. Control currents were measured in response to a $20 \mathrm{mV}$ hyperpolarization from $-80 \mathrm{mV}$ and used to calculate pipette resistance and linear capacitance of the ccll mcmbranc, as well as for digital subtraction of linear components of leak and capacitative currents from test currents. All recordings were made at room temperature $\left(\sim 20^{\circ} \mathrm{C}\right)$. In the majority of cells, rundown in the amplitude of calcium channel currents was minimal $(<20 \%)$ if the experiments were performed within $10-15$ min of breaking into the cell.

Isopropyl 4-(2,1,3-benzoxadiazol-4-yl)-1,4-dihydro-2,6-dimethyl-5nitro-3-pyridinecarboxylate [(+)-SDZ 202-791; kindly supplied by Dr.
A

B
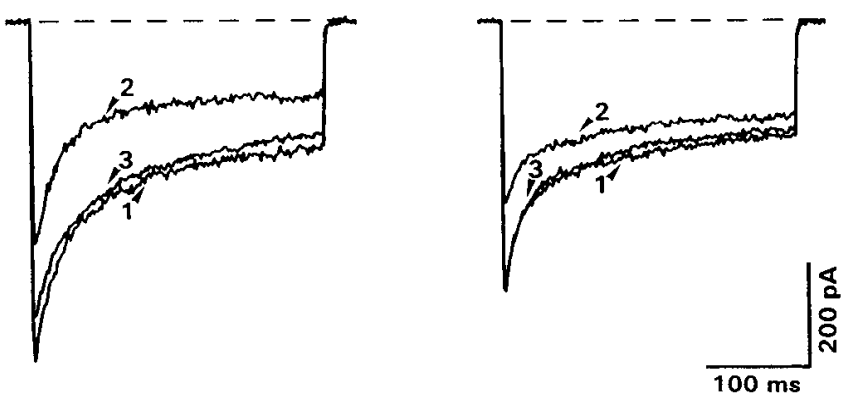

Figure 1. Examples of calcium channel currents in an identified mouse motoneuron before (trace 1) and during (trace 2) exposure to $40 \mu \mathrm{M}$ adenosine and after washout (trace 3 ). Currents were elicited by depolarizing steps to $+20 \mathrm{mV}$ from a holding potential of $-80 \mathrm{mV}$ with $10 \mathrm{~mm} \mathrm{Ca}^{2+}(A)$ or $10 \mathrm{~mm} \mathrm{Ba}^{2+}(B)$ as the charge carrier.

D. Römer and E. Rissi, Sandoz, Basel, Switzerland] was dissolved in $100 \%$ ethanol, diluted 500-1000-fold in the external solution, and applied to the cells by bath perfusion. Stock solutions of $\omega$-conotoxin GVIA (Peninsula Laboratories, Belmont, CA) were prepared by dissolving 0.5 $\mu \mathrm{g}$ of the peptide along with $1 \mathrm{mg}$ of bovine serum albumin into $2 \mathrm{ml}$ of $0.5 \%$ acetic acid. This solution was divided into aliquots, lyophilized, and stored at $-20^{\circ} \mathrm{C}$. On the day of the experiment, the $\omega$-conotoxin GVIA was diluted to a concentration of $10 \mu \mathrm{M}$ in external solution (final $\mathrm{pH} \approx 7.4$ ). Adenosine and 8-bromo-cAMP (both from Sigma Chemical Co., St. Louis, MO), $5^{t}-N$-ethylcarboxamide adenosine (NECA), $\mathrm{N}^{6}$ cyclohexyladenosine (CIIA), 2-p-(2-carboxyethyl)phencthylamino$5^{\prime}$ - $N$-ethylcarboxamido adenosine (CGS-21680), and 8-cyclopentyltheophylline (CPT) (all four from Research Biochemicals Inc., Natick, MA) were dissolved directly into external solution. The purinergic compounds were usually applied via a small-diameter, U-shaped polyethylene tube. The base of the U-tube, in which a small hole had been drilled, was positioned close $(\sim 100 \mu \mathrm{m})$ to the cell under study. One end of the U-tube was supplied with drug solution by gravity flow from a reservoir, and suction was applied to the other end (so that bath solution flowed into the small hole). Shutting off the suction led to the rapid application of drug solution (which was visualized with fast green). Reapplying suction rapidly cleared away the drug solution. The purinergic compounds were also occasionally applied with bath perfusion, but no differences were seen in comparing bath perfusion with U-tube application. Pertussis toxin was purchased from Sigma Chemical Co. (St. Louis, MO) and dissolved $(100 \mu \mathrm{g} / \mathrm{ml})$ in a $50 \%$ glycerol solution containing $50 \mathrm{~mm}$ sodium phosphate and $0.5 \mathrm{M} \mathrm{NaCl}, \mathrm{pH} 7.2$. This solution was added directly to the culture dishes $(4 \mu \mathrm{l}$ of solution in 2 $\mathrm{ml}$ of medium giving a final pertussis toxin concentration of $200 \mathrm{ng} /$ $\mathrm{ml}$ ) at least $1 \mathrm{hr}$ after plating the cells and allowed to remain in the dish until recording from the cells $16-22 \mathrm{hr}$ later. Data are expressed as mean \pm SEM.

\section{Results}

Figure 1 illustrates high-voltage-activated (HVA) calcium channel currents elicited in an identified embryonic mouse motoneuron by a $300 \mathrm{msec}$ depolarization to $+20 \mathrm{mV}$ applied before and during exposure to $40 \mu \mathrm{M}$ adenosine and after its washout; the charge carrier was $10 \mathrm{~mm} \mathrm{Ca}^{2+}$ (Fig. 1A) or $10 \mathrm{~mm} \mathrm{Ba}^{2+}$ (Fig. $1 B$ ). Adenosine decreased both the transient and sustained components of the HVA calcium channel current. For quantification, we defined the sustained component as the level of current remaining at the end of the $300 \mathrm{msec}$ depolarizing pulse. The transient component was calculated by subtracting the sustained component from the peak current. Figure 2 illustrates the current voltage relationship for the transient (Fig. 2A) and sustained (Fig. $2 B$ ) components of calcium current recorded in a single cell before, during, and after exposure to $40 \mu \mathrm{M}$ aden- 


\section{A. Transient}

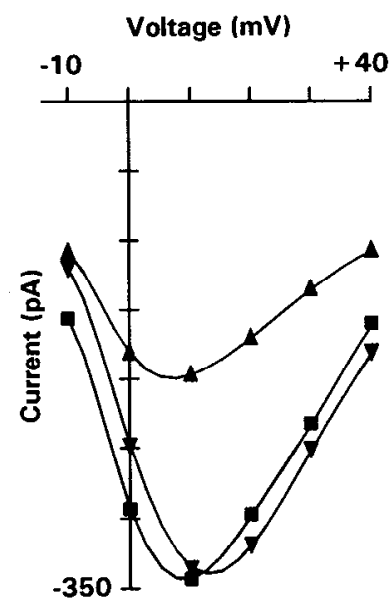

B. Sustained

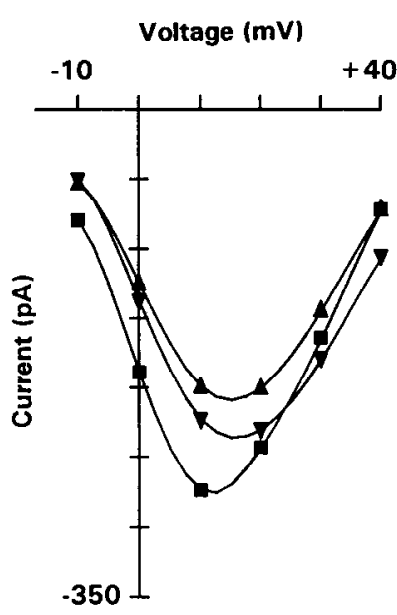

Figure 2. Current-voltage relation of calcium current in an identified mouse motoneuron before $(\square)$ and during ( $\Delta$ ) exposure to $40 \mu \mathrm{M}$ adenosine and after washout $(\boldsymbol{\nabla})$. Currents were elicited by $300 \mathrm{msec}$ depolarizing steps from a holding potential of $-80 \mathrm{mV}$ with $\mathrm{Ca}^{2+}$ as the charge carrier. The sustained current was defined as the current remaining at the end of the $300 \mathrm{msec}$ depolarizing pulse. The transient current was calculated by subtracting the sustained current from the peak current. The transient current $(A)$ was decreased by adenosine and recovered completely to control levels upon washout. The sustained current was also decreased by the addition of adenosine, but following washout did not fully return to control levels, suggesting that part of the decrease seen during exposure to adenosine may have been due to rundown of the current.

osine. The transient portion of the HVA current (Fig. $2 A$ ) was substantially decreased by adenosine and returned to control levels following washout. The decrease in sustained current (Fig. $2 B$ ) was less marked and failed to reverse completely upon washout. Thus, part of the decrease seen in the sustained current may reflect rundown of the current rather than a true effect of adenosine.

Since we have previously shown that $\mathrm{T}$-channels contribute relatively little to the total current elicited by a depolarizing pulse to $+20 \mathrm{mV}$ (Mynlieff and Beam, 1992a,b), the average effect of adenosine on HVA current was measured at this test potential using either $\mathrm{Ba}^{2+}$ or $\mathrm{Ca}^{2+}$ as the charge carrier. Adenosine $(40 \mu \mathrm{M})$ decreased the transient HVA calcium channel current $26.7 \pm 10.0 \%(n=3)$ and $28.8 \pm 3.6 \%(n=9)$, with $\mathrm{Ba}^{2+}$ or $\mathrm{Ca}^{2+}$ as the charge carrier, respectively. The sustained component of calcium channel current was decreased $34.7 \pm$ $21.2 \%(n=3)$ and $23.2 \pm 2.7 \%(n=9)$, respectively, with $\mathrm{Ba}^{2+}$ or $\mathrm{Ca}^{2+}$ as the charge carrier. These numbers were calculated by comparing the current in the presence of adenosine to the current prior to the exposure to adenosine. In the majority of the cells the current did not completely recover to control levels upon washout of the adenosine. If the currents measured during the application of adenosine were compared to the average of the pre- and postadenosine currents, it yielded a slightly smaller but still significant inhibition of $25.8 \pm 3.0 \%(n=9)$ and 19.3 $\pm 4.4 \%(n=9)$, respectively, for the transient and sustained HVA components $\left(\mathrm{Ca}^{2+}\right.$ as charge carrier). For simplicity, all of the subsequent data will be expressed as an inhibition of the preadenosine current.

Figure 3 illustrates the effect of various purinergic compounds on the HVA current in motoneuron-like cells (see Materials and

A

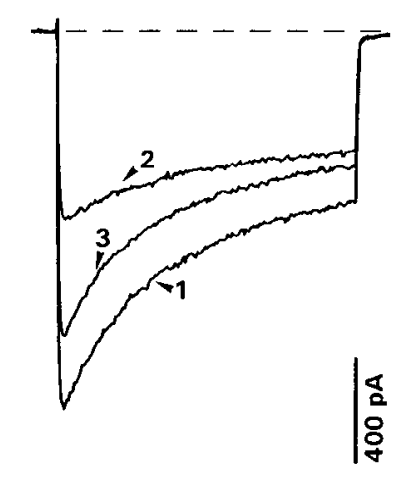

C

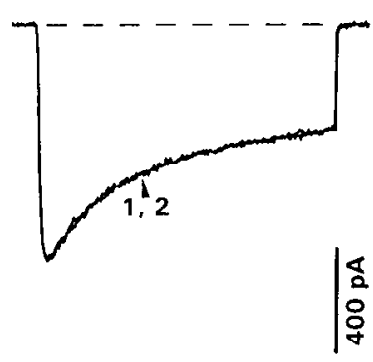

B

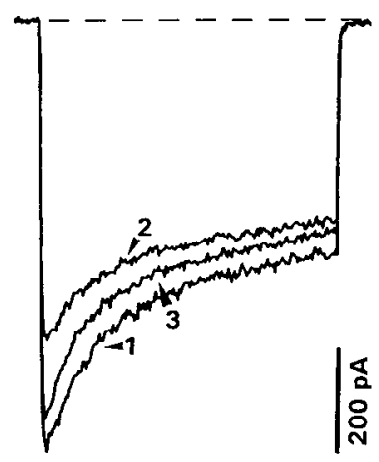

D

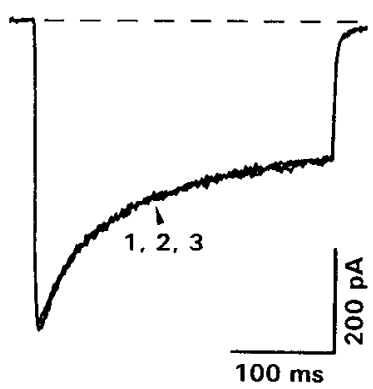

Figure 3. Whole-cell calcium currents recorded in mouse motoneuronlike cells before (trace I) and during (trace 2) exposure to, and after washout (trace 3) of, various purinergic compounds. Test potential was $+20 \mathrm{mV}$ and $\mathrm{Ca}^{2+}$ was the charge carrier. Both the nonselective adenosine agonist NECA, at a concentration of $250 \mathrm{nM}(A)$, and the A1selective agonist CHA, at a concentration of $10 \mu \mathrm{M}(B)$, caused a decrease in whole-cell calcium current that was partially reversed upon washout. Whole-cell calcium currents were unaffected by the A2-selective agonist CGS-21680, at a concentration of $1 \mu \mathrm{M}(C)$, or by the nonselective agonist NECA ( $250 \mathrm{~nm}$ ) when applied in the presence of $100 \mathrm{~nm}$ CPT, an Al-selective antagonist $(D)$.

Methods). Like adenosine, the nonselective adenosine agonist NECA (Bruns et al., 1986) inhibited both the transient and sustained components of HVA current (Fig. $3 A$ ). This inhibition of current appears to be mediated by an Al receptor since the Al-selective agonist CHA (Bruns et al., 1986) mimicked the effect of NECA (Fig. $3 B$ ) but the A2a-selective agonist CGS21680 (Ji et al., 1992) did not (Fig. 3C), and because the presence of the Al antagonist CPT (Bruns et al., 1986) prevented the action of NECA (Fig. 3D). Figure 4 illustrates dose-response curves for the inhibition by NECA and CHA of the total HVA calcium current elicited by a $300 \mathrm{msec}$ depolarizing step to +20 $\mathrm{mV}$. For NECA, the $\mathrm{EC}_{50}$ was $28 \mathrm{~nm}$ and the maximal inhibition was $38 \%$. For CHA, the $\mathrm{EC}_{50}$ was $30 \mathrm{nM}$ and the maximal inhibition was $31 \%$. With a maximal inhibition of $38 \%$, NECA was more efficacious than either CHA or adenosine (maximal inhibition of approximately $30 \%$ ) in decreasing the HVA calcium current.

To test the involvement of a $G$ protein in the adenosine response, we pretreated spinal cord cultures with $200 \mathrm{ng} / \mathrm{ml}$ pertussis toxin for 16-24 hr. Figure $5 A$ shows that NECA ( 250 nM) had very little effect on HVA calcium currents in a motoneuron-like cell pretreated with pertussis toxin. In such cells, the average inhibition in response to $250 \mathrm{nM}$ NECA was 12.5 $\pm 6.2 \%(n=9)$ and $8.2 \pm 3.3 \%(n=9)$ for the transient and sustained components of HVA calcium current, respectively ( 10 $\mathrm{mM} \mathrm{Ca}^{2+}$ as the charge carrier). This is in contrast to untreated 


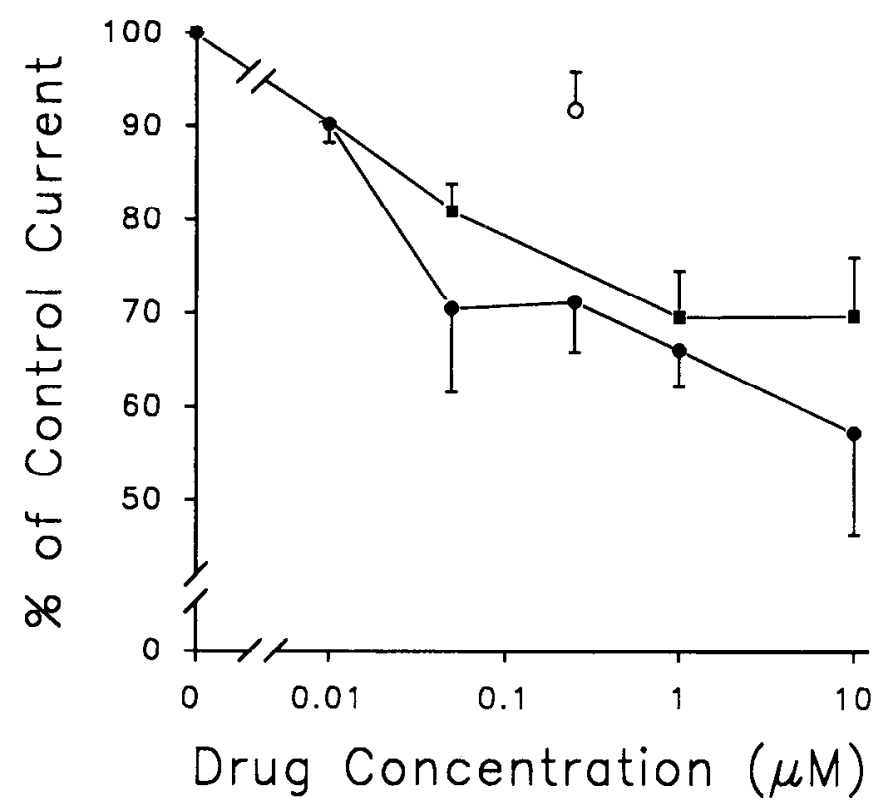

Figure 4. Depression of peak calcium current in mouse motoneuronlike cells in response to varying concentrations of NECA (O) and CHA (D). Currents were elicited by a $300 \mathrm{msec}$ depolarizing step to $+20 \mathrm{mV}$ from a holding potential of $-80 \mathrm{mV}$ with $\mathrm{Ca}^{2+}$ as the charge carrier. In the presence of $100 \mathrm{nM} C P T, 250 \mathrm{nM}$ NECA $(O)$ had little effect. The data are presented as mean \pm SEM with $n=4-16$ for each point.

cells where the average inhibition was $39.2 \pm 7.4 \%(n=5)$ and $20.6 \pm 3.5 \%(n=4)$ for the transient and sustained components of HVA current, respectively. These data indicate that a pertussis toxin-sensitive $G$ protein mediates the effects of adenosine on HVA calcium currents in mouse motoneurons.

In many systems, activation of the $\mathrm{A} 1$ adenosine receptor has been shown to inhibit adenylate cyclase activity via $\mathrm{Gi}$, a pertussis toxin-sensitive $G$ protein (Olah and Stiles, 1992). Accordingly, if intracellular cAMP were stimulatory for motoneuronal HVA calcium current, then the depression of this current by $\mathrm{A} 1$ receptor activation could be explained by a drop in cAMP level. Thus, we tested whether application of a cAMP analog, 8-bromo-cAMP, had a stimulatory effect on the caicium current in motoneurons. Figure $5 B$ shows that $1 \mathrm{~mm}$ 8-bromo-cAMP actually caused a slight decrease in the HVA calcium current. On average, $1 \mathrm{~mm} 8$-bromo-cAMP caused a $17.4 \pm 7.7 \%(n=$ 5) and $29.0 \pm 14.2 \%(n=6)$ inhibition of the transient and sustained components, respectively, when currents were elicited by a step depolarization to $+20 \mathrm{mV}\left(\mathrm{Ca}^{2+}\right.$ as the charge carrier). Only cells that exhibited a washout of the effect were included in these averages. These data suggest that inhibition of adenylate cyclase does not account for the reduction in HVA calcium current in motoneurons that is produced by $\mathrm{A} 1$ receptor activation.

To determine whether inhibition of current through L-type channels was involved in the reduction of HVA current by adenosine, we used the dihydropyridine agonist (+)-SDZ 202$791(1 \mu \mathrm{M})$. In the presence of SDZ 202-791, L-type current is potentiated, activates at more hyperpolarized potentials, and deactivates more slowly. The slowed deactivation is recognizable as a slow component of tail current that is not present prior to exposure to the dihydropyridine and is thought to be carried solely by L-type channels (Plummer et al., 1989; Kegan et al., 1991). Figure $6 A$ illustrates, for a test depolarization to +20
A

B
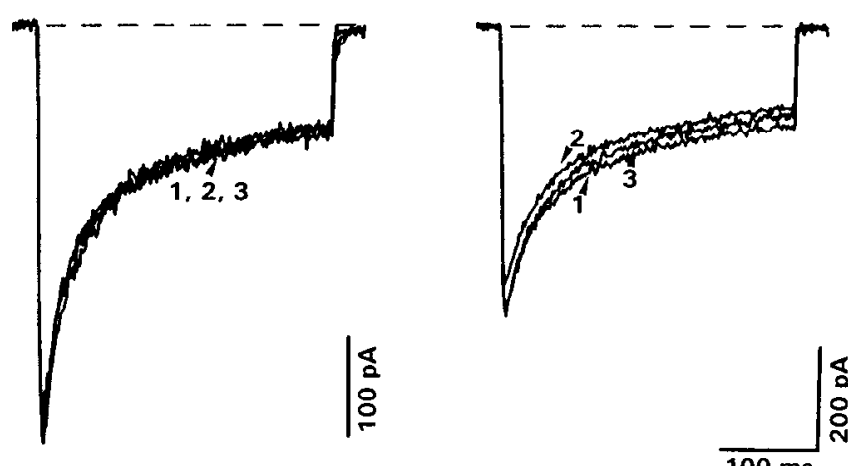

옹

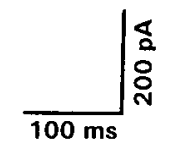

Figure 5. Role of intracellular signaling molecules in the depression of calcium current by adenosine receptor activation. $A$, Effect of pertussis toxin pretreatment on the response of a motoneuron-like cell to NECA. Calcium currents were recorded before (trace 1 ) and during (trace 2) exposure to $250 \mathrm{~nm} \mathrm{NECA}$, and after washout (trace 3). Cells were treated with $200 \mathrm{ng} / \mathrm{ml}$ pertussis toxin for 18-24 hr prior to recording. $B$, Calcium currents recorded from a motoneuron-like cell before (trace 1) and during (trace 2) exposure to $1 \mathrm{~mm} \mathrm{8-bromo-cAMP,} \mathrm{and} \mathrm{after}$ washout (trace 3). In both $A$ and $B$, the test potential was $+20 \mathrm{mV}$ and $\mathrm{Ca}^{2+}$ was the charge carrier.

$\mathrm{mV}$, that the calcium channel current in an identified motoneuron in the presence of SDZ 202-791 (trace 2) was potentiated compared to the current measured in the same cell prior to drug addition (trace 1); the subsequent addition of $40 \mu \mathrm{M}$ adenosine (SDZ 202-791 still present) caused a partial inhibition of the current. Figure $6 B$ illustrates tail currents recorded from the same cell upon repolarization to $-80 \mathrm{mV}$ after a $300 \mathrm{msec}$
A

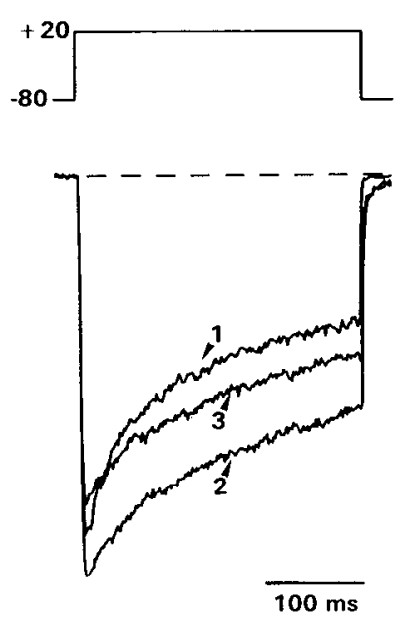

B
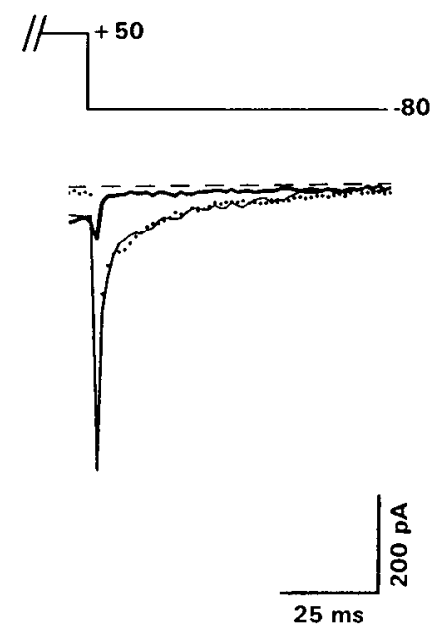

Figure 6. Absence of effect of adenosine on current through L-type channels. $A$, Whole-cell currents recorded in an identified mouse motoneuron before application of (+)-SDZ 202-791 (trace 1), during $1 \mu \mathrm{M}$ $(+)-\mathrm{SDZ} 202-791$ perfusion (trace 2), and during perfusion with both $1 \mu \mathrm{M}(+)-\mathrm{SDZ} 202-791$ and $40 \mu \mathrm{M}$ adenosine (trace 3 ). The test potential was $+10 \mathrm{mV} . B$, Tail currents recorded from the same cell as in $A$ before application of (+)-SDZ 202-791 (thick trace), during $1 \mu \mathrm{M}(+)-S D Z$ 202-791 perfusion (thin trace), and during perfusion with $1 \mu \mathrm{M}(+)-\mathrm{SDZ}$ 202-791 and $40 \mu \mathrm{M}$ adenosine (dotted trace). The repolarization to -80 $\mathrm{mV}$ was preceded by a $300 \mathrm{msec}$ depolarization to $+50 \mathrm{mV}$. In both $A$ and $B, \mathrm{Ba}^{2+}$ was the charge carrier. 
A

B
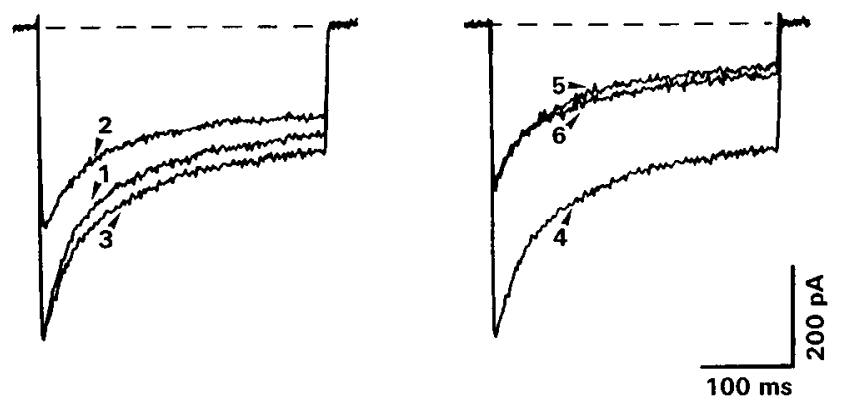

Figure 7. The adenosine agonist NECA affects only the $\omega$-conotoxinsensitive component of HVA calcium current. $A$, Calcium currents recorded before (trace 1 ) and during (trace 2) exposure to $1 \mu \mathrm{M} \mathrm{NECA}$ and after washout (trace 3 ). $B$, Calcium currents recorded before treatment with $\omega$-conotoxin GVI $($ trace 4 , a replot of trace 3), following the washout after a 3 min exposure to $10 \mu \mathrm{M} \omega$-conotoxin GVIA (trace 5 ), and during a second exposure to $1 \mu \mathrm{M} \mathrm{NECA} \mathrm{(trace} \mathrm{6).} \mathrm{All} \mathrm{the} \mathrm{traces}$ were obtained from a single, motoneuron-like cell in the indicated numerical order. In both $A$ and $B$, the test potential was $+20 \mathrm{mV}$ and $\mathrm{Ca}^{2+}$ was the charge carrier.

depolarization to $+50 \mathrm{mV}$. The control tail current (thick trace) does not show the slow component of decay that was evident after the addition of $1 \mu \mathrm{M}$ SDZ 202-791 (thin trace). Adenosine (dotted trace) did not decrease the slow component of tail current. Thus, it appears that the inhibition of HVA current by adenosine must involve an action upon channels that are not $\mathrm{L}$ type.

Block by $\omega$-conotoxin GVIA was used to examine the role of $\mathrm{N}$-type channels in the reduction of HVA current by adenosine. Experiments involving heterologous expression of cloned cDNAs have demonstrated that $\omega$-conotoxin GVIA blocks N-type channels in a relatively irreversible fashion (Williams et al., 1992a; Fujita et al., 1993). However, the toxin (at micromolar concentrations) also blocks a cloned L-type channel (Williams et al., $1992 \mathrm{~b}$ ) and an unidentified component of HVA current in motoneurons (Mynlieff and Beam, 1992a) in a reversible fashion. Thus, we applied the following experimental protocol to motoneuron-like cells $\left(\mathrm{Ca}^{2+}\right.$ was the charge carrier). First, the most potent adenosine agonist, NECA, was tested on each cell prior to treatment with $\omega$-conotoxin GVIA so that the cell could act as its own control. Second, the cell was exposed to $10 \mu \mathrm{M} \omega$-conotoxin GVIA for a minimum of $3 \mathrm{~min}$ and then washed. Only those components of HVA current not arising from N-type channels would be expected to remain after this treatment. Third, NECA was once again applied to the cell. Figure 7 illustrates an example of one cell throughout this entire protocol. Figure $7 A$ shows that NECA caused a reversible inhibition of HVA current. On average, the decrease in total HVA current produced by $1 \mu \mathrm{M}$ NECA was $22.2 \pm 3.4 \%(n=5)$. Figure $7 B$ shows the current before (trace 4 ) and after (trace 5) the treatment with $\omega$-conotoxin GVIA (which caused an average inhibition of 42.4 $+5.2 \%, n=5$ ) and during the subsequent reexposure to NECA (trace 6). After the period of treatment with $\omega$-conotoxin GVIA, NECA was essentially without effect on this or the other cells examined $(5.5 \pm 5.1 \%$ increase in current, $n=5)$. Thus, it appears the reduction of HVA current by adenosine can be almost exclusively attributed to an inhibition of $\mathrm{N}$-type calcium channels.

\section{Discussion}

We have shown here that adenosine decreases both transient and sustained components of HVA whole-cell calcium current in embryonic mouse motoneurons. Of the pharmacologically identifiable types of channel that contribute to HVA calcium currents in motoneurons, only N-type channels appear to be inhibited. The effect of adenosine on N-type channels, like that of adenosine on mammalian neuromuscular transmission (Silinsky et al., 1989; Sebastiao et al., 1990; Correia-de-Sá et al., 1991), is mediated by an Al adenosine receptor coupled to a pertussis toxin-sensitive $\mathrm{G}$ protein.

It has been well documented that activation of $\mathrm{Al}$ receptors can inhibit adenylate cyclase via a pertussis toxin-sensitive $G$ protein (van Calker et al., 1979; Olah and Stiles, 1992). If basal levels of cAMP in motoneurons were sufficient to maintain the HVA calcium current in a partially potentiated state, then inhibition of adenylate cyclase could account for the inhibition of current by adenosine. However, this pathway does not appear to be responsible for the reduction in motoneuronal HVA current by adenosine, since exposure to 8-bromo-cAMP failed to increase the HVA current, causing instead a small decrease. This small decrease could be explained if adenosine receptors were directly activated by 8 -bromo-cAMP at the high concentration (1 $\mathrm{mm}$ ) used in our experiments. Alternatively, it is possible that activation of protein kinase $\mathrm{A}$ decreases motoneuronal calcium current.

Evidence from a number of systems suggests that a direct interaction between $G$ proteins and calcium channels can modulate current through the channels (Yatani et al., 1987, 1988). Biochemical evidence indicates that the adenosine $\mathrm{A} 1$ receptor could potentially interact with Gil, Gi2, Go (Munshi et al., 1991), and Gi3 (Freissmuth et al., 1991). Since all of these $G$ proteins are inactivated by pertussis toxin pretreatment, they are all candidates as intracellular mediators for the inhibition of motoneuronal HVA calcium current by adenosine. Establishing the identity of the $G$ protein involved in this inhibition of current and determining whether the inhibition involves a direct interaction between $G$ protein and channel are important areas of future investigation.

L-type channels, as revealed by a slowly deactivating component of current in the presence of a dihydropyridine agonist, were unaffected by adenosine. Moreover, once all of the N-type current was irreversibly inhibited by pretreatment with $\omega$-conotoxin GVIA, purinergic compounds had essentially no effect on the remaining HVA calcium current. This result confirms that adenosine does not affect L-type channels and further indicates that adenosine does not affect any other HVA calcium channels (P-type or other) that are insensitive to $\omega$-conotoxin GVIA. In this respect, embryonic mouse motoneurons differ from young adult guinea pig CA3 hippocampal pyramidal neurons, where adenosine causes potentiation of P-type channels in addition to an inhibition of N-type channels (Mogul et aí., 1993). Because embryonic motoncurons appear to express P-type calcium channels (S. Ho and K. G. Beam, unpublished observations), it would seem that the classes of calcium channels affected by adenosine vary from one cell type to another. However, differences in species, developmental age, and cell type may also be important factors in determining which calcium channels are targeted by adenosine.

The identity of the calcium channel controlling neurotransmitter release in the neuromuscular junction has been investi- 
gated with the usc of toxins. In the carliest studies it was shown that $\omega$-conotoxin GVIA irreversibly inhibited synaptic transmission at the frog neuromuscular junction but had no effect at the mammalian neuromuscular junction (Olivera et al., 1984; Sano et al., 1987). More recently, studies on the mouse neuromuscular junction have shown that, under circumstances where synaptic transmission is compromised, $\omega$-conotoxin GVIA does reversibly decrease the end-plate potential (Hong et al., 1992). However, this reversible decrease probably does not mean that $\mathrm{N}$-type channels are involved in mammalian neuromuscular transmitter release because the effects of $\omega$-conotoxin GVIA on N-type channels appear to be essentially irreversible (Fox et al., 1987; Williams et al., 1992a; Fujita et al., 1993). Furthermore, neuronal calcium channels that are molecularly distinct from $\mathrm{N}$-type channels have been shown to be reversibly blocked by conotoxin at micromolar concentrations (Williams et al., 1992b; Ellinor et al., 1993) and recent evidence suggests that P-channels control neuromuscular transmission in mammals (Uchitel et al., 1992; Ho and Beam, unpublished observations). Thus, it appears that different types of calcium channels subserve neuromuscular transmission in the mouse and frog. An alternative possibility is that neuromuscular transmission in the two species is carried out by calcium channels of similar type but dissimilar pharmacology. Molecular genetic analysis will be necessary to distinguish between these possibilities. In any case, the observed inhibition of N-type ( $\omega$-conotoxin-GVIA-sensitive) calcium current by adenosine seems unlikely to be involved in the adenosine-mediated inhibition of neuromuscular transmission in the mouse. Rather, as in the rat hippocampus (Scholz and Miller, 1992) and frog neuromuscular junction (Hunt et al., 1992; Redman and Silinsky, 1992), it seems likely that adenosine depresses murine neuromuscular transmission by mechanisms not involving changes in calcium currents.

As described in Materials and Methods, our experiments involved measurements of calcium currents in neurons that were dissociated and maintained in culture for 12-24 hr. Although the axon and fine dendrites become separated from the soma during dissociation, our working (but untested) hypothesis has been that placing the dissociated neurons in culture allows them to express calcium channels that are characteristic of both the soma and axon terminal in vivo. This hypothesis receives support from the demonstration that, in vivo, the neuronal cell bodies giving rise to squid giant axons lack sodium channels, but following axotomy and placement in tissue culture the cell bodies begin to express sodium channels functionally indistinguishable from those of the axon (Brismar and Gilly, 1987; Gilly and Brismar, 1989).

The demonstration that low concentrations (10 nM) of $\omega$-conotoxin GVIA inhibit the extracellularly recorded calcium current in rat motor nerve terminals (Hamilton and Smith, 1992) provides direct evidence for the presence of $\mathrm{N}$-type channels in the presynaptic terminal of the rodent neuromuscular junction. Moreover, adenosine causes a decrease in the extracellularly recorded calcium current of rat motor nerve terminals (Hamilton and Smith, 1991, 1992). It seems very likely that this decrease in the cxtraccllularly recorded calcium current reflects an action of adenosine on presynaptic $\mathrm{N}$-type channels given our observation that adenosine affects only $\mathrm{N}$-type channels in cultured mouse motoneurons.

At the frog neuromuscular junction, $\omega$-conotoxin-GVIA-sensitive channels are present in the presynaptic terminal, are critical for neurotransmitter release, and do not appear to be affected by adenosine (Redman and Silinsky, 1992; Silinsky and Solsona, 1992). By contrast, $\omega$-conotoxin-GVIA-sensitive channels are present in rodent motor terminals, are not critical for neurotransmitter release, and $d o$ appear to be modulated by adenosine. Thus, the question arises of what presynaptic functions might be affected by this modulation. Perhaps, $\omega$-conotoxinGVIA-sensitive (N-type) channels in the rodent play a role in use-dependent effects on neurotransmitter release or in regulating enzymatic activities within the presynaptic terminal. Further studies are needed on the role of $\mathrm{N}$-type calcium channels in the mammalian neuromuscular junction before the consequences of adenosine inhibition of N-type current can be addressed.

\section{References}

Adams B, Beam KG (1989) A novel calcium current in dysgenic skclctal muscle. J Gen Physiol 94:429-444.

Brismar T, Gilly WF (1987) Synthesis of sodium channels in the cell bodies of squid giant axons. Proc Natl Acad Sci USA 84:1459-1463.

Bruns RF, Lu GH, Pugsley TA (1986) Characterization of the $\mathrm{A}_{2}$ adenosine receptor labeled by $\left[{ }^{3} \mathrm{H}\right] \mathrm{NECA}$ in rat striatal membranes. Mol Pharmacol 29:331-346.

Correia-de-Sá P, Sebastiao AM, Ribeiro JA (1991) Inhibitory and excitatory effects of adenosine receptor agonists on evoked transmitter release from phrenic nerve endings of the rat. $\mathrm{Br} \mathrm{J}$ Pharmacol 103: $1614-1620$.

Dolphin AC, Archer ER (1983) Adenosine agonist inhibits and a cyclic AMP analogue enhances the release of glutamate but not GABA from slices of rat dentate gyrus. Neurosci Lett 43:49-54.

Dolphin AC, Forda SR, Scott RH (1986) Calcium-dependent currents in cultured rat dorsal root ganglion neurones are inhibited by an adenosine analogue. J Physiol (Lond) 373:47-61.

Ellinor PT, Zhang J-F, Randall AD, Zhou M, Schwarz TL, Tsien RW, Horne WA (1993) Functional expression of a rapidly inactivating neuronal calcium channel. Nature 363:455-458.

Fox AP, Nowycky MC, Tsien RW (1987) Kinetic and pharmacological properties distinguish three types of calcium currents in chick sensory neurons. J Physiol (Lond) 394:149-172.

Fredholm BB (1976) Release of adenosine-like material from isolated perfused dog adipose tissue following sympathetic nerve stimulation and its inhibition by adrenergic alpha-receptor blockade. Acta Physiol Scand 96:122-130.

Freissmuth M, Schütz W, Linder ME (1991) Interactions of the bovine brain $\mathrm{A} 1$-adenosine receptor with recombinant $\mathrm{G}$ protein $\alpha$-subunits. J Biol Chem 266:17778-17783.

Fujita Y, Mynlieff M, Dirksen RT, Kim M-S, Niidome T, Nakai J, Friedrich T, Iwabe N, Miyata T, Furuichi T, Furutama D, Mikoshiba K, Mori Y, Beam KG (1993) Primary structure and functional expression of the $\omega$-conotoxin-sensitive N-type calcium channel from rabbit brain. Neuron 10:585-598.

Gerber U, Greene RW, Hass HL, Stevens DR (1989) Characterization of inhibition mediated by adenosine in the hippocampus of the rat in vitro. J Physiol (Lond) 417:567-578.

Gilly WF, Brismar T (1989) Properties of appropriately and inappropriately expressed sodium channels in squid giant axon and it somata. J Neurosci 9:1362-1374.

Ginsborg BL, Hirst GDS (1972) The effect of adenosine on the release of the transmitter from the phrenic nerve of the rat. J Physiol (Lond) 224:629-645.

Gross RA, Macdonald RL, Ryan-Jastrow T (1989) 2-Chloroadenosine reduces the $\mathrm{N}$ calcium current of cultured mouse sensory neurones in a pertussis toxin-sensitive manner. J Physiol (Lond) 41 1:585-595.

Hamill OP, Marty A, Neher E, Sakmann B, Sigworth FJ (1981) Improved patch-clamp techniques for high-resolution current recording from cells and cell-free membrane patches. Pfluegers Arch 391:85100.

Hamilton BR, Smith DO (1991) Autoreceptor-mediated purinergic and cholinergic inhibition of motor nerve terminal calcium currents in the rat. J Physiol (Lond) 432:327-341.

Hamilton BR, Smith DO (1992) Calcium current in rat motor nerve terminals. Brain Res 584:123-131.

Hong SJ, Tsuji K, Chang CC (1992) Inhibition by neosurugatoxin and 
$\omega$-conotoxin of acetylcholine release and muscle and neuronal nicotinic receptors in mouse neuromuscular junction. Neuroscience 48: $727-735$.

Hunt JM, Wilfehrt HM, Silinsky EM (1992) Adenosine inhibits the calcium-dependent acetylcholine secretion induced by ionomycin. Soc Neurosci Abstr 18:636.

Ji X-D, Stiles GL, van Galen PJM, Jacobson KA (1992) Charactcrization of human striatal $\mathrm{A}_{2}$-adenosine receptors using radioligand binding and photoaffinity labeling. J Recept Res 12:149-169.

Miyamoto MD, Breckenridge BMcL (1974) A cyclic adenosine monophosphate link in the catecholamine enhancement of transmitter release at the neuromuscular junction. J Gen Physiol 63:609-624

Mogul DJ, Adams ME, Fox AP (1993) Differential activation of adenosine receptors decreases $\mathrm{N}$-type but potentiates $\mathrm{P}$-type $\mathrm{Ca}^{2+}$ current in hippocampal CA3 neurons. Neuron 10:327-334.

Munshi R, Pang I, Sternweis PC, Linden J (1991) A1 adenosine receptors of bovine brain couple to guanine nucleotide-binding proteins Gi1, Gi2, and Go. J Biol Chem 266:22285-22289.

Mynlieff M, Beam KG (1992a) Characterization of calcium currents in identified mouse motoneurons. J Neurophysiol 68:85-92.

Mynlieff M, Beam KG (1992b) Devclopment of calcium currents in identified mouse motoneurons. Dev Biol 152:407-410.

Olah ME, Stiles GL (1992) Adenosine receptors. Annu Rev Physiol 54:211-225.

Olivera BM, McIntosh JM, Cruz LJ, Luque FA, Gray WR (1984) Purification and sequence of presynaptic peptide toxin from Conus geographus venom. Biochemistry 23:5087-5090.

Plummer MR, Logothetis DE, Hess P (1989) Elementary properties and pharmacological sensitivities of calcium channels in mammalian peripheral neurons. Neuron 2:1453-1463.

Prince DA, Stevens CF (1992) Adenosine decreases neurotransmitter release at central synapses. Proc Natl Acad Sci USA 89:8586-8590.

Redman RS, Silinsky EM (1992) Endogenous adenosine mediates neuromuscular depression without affecting calcium currents in the frog. Soc Neurosci Abstr 18:1132.

Regan LJ, Sah DWY, Bean BP (1991) $\mathrm{Ca}^{2+}$ channels in rat central and peripheral neurons: high-threshold current resistant to dihydropyridine blockers and $\omega$-conotoxin. Neuron 6:269-280.

Ribeiro JA, Walker J (1975) The effects of adenosine triphosphate and adenosine diphosphate on transmission at the rat and frog neuromuscular junction. Br J Pharmacol 54:213-218.

Ribeiro JA, Sebastiao AM (1987) On the role, inactivation and origin of endogenous adenosine at the frog neuromuscular junction. J Physiol (Lond) 384:571-585.

Sano K, Enomoto K, Maeno T (1987) Effects of synthetic $\omega$-conotoxin, a new type $\mathrm{Ca}^{2+}$ antagonist, on frog and mouse neuromuscular transmission. Eur J Pharmacol 141:235-241.

Scholz KP, Miller RJ (1991) Analysis of adenosine action on $\mathrm{Ca}^{2+}$ currents and synaptic transmission in cultured rat hippocampal pyramidal neurones. J Physiol (Lond) 435:373-393.

Scholz KP, Miller RJ (1992) Inhibition of quantal transmitter release in the absence of calcium influx by a $G$ protein-linked adenosine receptor at hippocampal synapses. Neuron 8:1139-1150.

Sebastiao AM, Stone TW, Ribeiro JA (1990) The inhibitory adenosine receptor at the ncuromuscular junction and hippocampus of the rat: antagonism by 1.3.8-substituted xanthines. Br J Pharmacol 101:453459.

Silinsky EM (1988) The influence of 2-chloroadenosine on potassiumevoked and neurally-evoked acetylcholine secretion from normal or from latent active zones in the frog. Br J Pharmacol 93:833-838.

Silinsky EM, Solsona CS (1992) Calcium currents at motor nerve endings: absence of effects of adenosine receptor agonists in the frog. J Physiol (Lond) 457:315-328.

Silinsky EM, Solsona C, Hirsh JK (1989) Pertussis toxin prevents the inhibitory effect of adenosine and unmasks adenosine-induced excitation of mammalian motor nerve endings. Br J Pharmacol 97:1618.

Smith DO, Lu Z (1991) Adenosine derived from hydrolysis of presynaptically rclcascd ATP inhibits ncuromuscular transmission in the rat. Neurosci Lett 122:171-173.

Uchitel OD, Protti DA, Sanchez V, Cherskey BD, Sugimori M, Llinas R (1992) P-type voltage-dependent calcium channel mediates presynaptic calcium influx and transmitter release in mammalian synapses. Proc Natl Acad Sci USA 89:3330-3333.

van Calker D, Müller M, Hamprecht B (1979) Adenosine regulates via two different types of receptors, the accumulation of cyclic AMP in cultured brain cells. J Neurochem 33:999-1005.

Verhaege RH, Vanhoutte PM, Shepard JT (1977) Inhibition of sympathetic neurotransmission in canine blood vessels by adenosine and adenine nucleotides. Circ Res 40:208-215.

Williams ME, Burst PF, Feldman DH, Patthi S, Simerson S, Maroufi A, McCur AF, Veliçelebi, Ellis SB, Harpold MM (1992a) Structure and functional expression of an $\omega$-conotoxin-sensitive human $\mathrm{N}$-typc calcium channel. Science 257:389-395.

Williams ME, Feldman DH, McCue AF, Brenner R, Velicelebi G, Ellis SB, Harpold MM (1992b) Structure and functional expression of $\alpha_{1}, \alpha_{2}$, and $\beta$ subunits of a novel human neuronal calcium channel subtype. Neuron 8:71-84.

Yatani A, Codina J, Imoto Y, Reeves JP, Birnbaumer L, Brown AM (1987) A G-protein directly regulates mammalian cardiac calcium channels. Science 238:1288-1291.

Yatani A, Imoto Y, Codina J, Hamilton SL, Brown AM, Birnbaumer L (1988) The stimulating G-protein of adenylyl cyclase, Gs, also stimulates dihydropyridine-sensitive $\mathrm{Ca}^{2+}$ channels. J Biol Chem 263: 9887-9895. 